Vol. 1, No. 1, Juni 2020

\title{
SPEKTA
}

Jurnal Pengabdian Kepada Masyarakat : Teknologi dan Aplikasi

Journal homepage :

http://journal2.uad.ac.id/index.php/spekta

\section{PEMANFAATAN TEPUNG LABU KUNING MODIFIKASI HYDROGEN RICH WATER KEPADA MASYARAKAT}

\section{Gita Indah Budiarti*, Ayu Wulandari, Siti Mutmaina}

Program Studi Teknik Kimia, Universitas Ahmad Dahlan, Jl. Ringroad Selatan, Kragilan, Tamanan, Kec. Banguntapan, Bantul, Yogyakarta, DI Yogyakarta, Indonesia

\section{INFO ARTIKEL}

Diterima : April 2020

Direvisi : Mei 2020

Disetujui : Mei 2020

\section{Keywords:}

Pumpkin flour;

Hydrogen Rich Water;

Physicochemical character

\begin{abstract}
Pumpkin flour is one alternative wheat substitute flour that has an advantage in terms of nutritional value, other than that the pumpkin fruit in Indonesia is quite abundant so it is potential to be used as food as well as subtituen wheat flour. The purpose of this research is to know the effect of treatment by soaking the pumpkin using hydrogen rich water to the physicochemical characteristics of starch as well as the texture, aroma and taste of processed pumpkin flour cake. The method done is to immersion using hydrogen rich water pH 5 and 9 for 1, 2, 3, 4 and 5 hours and then dried using a microwave and mashed with a blender then sifted using screening. Analysis conducted favorite test. The results showed that in the processed cakes shows the texture, aroma and distinctive flavor of the yellow pumpkin. Pumpkin flour is good to be used as a mixture of wheat flour in the manufacturing of various food processed such as wet cakes and biscuits.
\end{abstract}

\section{PENDAHULUAN}

Konsumsi tepung terigu di Indonesia terus meningkat sejalan dengan tumbuhnya konsumsi mie instan, roti, biskuit dan cookies. Berdasarkan data Badan Pusat Statistik (BPS) tahun 2018, volume impor komoditas gandum-ganduman mengalami kenaikan 4\% dibandingkan tahun sebelumnya menjadi 5,97 juta ton atau setara US\$1,73 miliar. Sumber pangan karbohidrat rendah gula menjadi pilihan terbaik untuk diet ketogenik, terutama bagi penderita diabetes melitus. Laporan WHO menyebutkan bahwa pre-valensi diabetes di seluruh dunia yang menca- pai sekitar $2,8 \%$ pada tahun 2000, diperkirakan meningkat menjadi 4,4\% pada tahun 2030. Total penderita diabetes meningkat dari 171 juta jiwa pada tahun 2000 menjadi 366 juta jiwa pada tahun 2030. Jumlah kasus diabetes di seluruh dunia pada tahun 2000 di antara orang dewasa berusia 20 tahun lebih tinggi $11 \%$ dari perkiraan sebelumnya yang hanya menyebut 154 juta. WHO juga mengungkapkan bahwa pada tahun 2004, penduduk dunia menderita diabetes sudah mencapai 200 juta jiwa Indonesia dengan penderita diabetes sebanyak 8,4 juta orang menempati urutan keempat sebagai Negara ber- penduduk diabetes terbanyak baik pada tahun 2000 maupun 2030. diperkirakan bahwa pada tahun 2030 prevalensi Diabetes Mellitus (DM) di Indonesia

\footnotetext{
* Corresponding author

E-mail address: gita.indah@che.uad.ac.id 
Vol. 1, No. 1, Juni 2020

mencapai 21,3 juta orang (Jayaningrum, 2016). Salah satu cara mencegah diabetes yaitu dengan diet ketogenik. Diet ketogenik merupakan pola makan yang berfokus pada asupan makanan tinggi lemak serta rendah karbohidrat, dengan kandungan lemaknya mencapai 70-90 \% atau 3 sampai 4 kali lebih besar dari kandungan karbohidrat dan protein. Oleh karena itu, potensi untuk penggunaan tepung labu kuning sebagai salah satu campuran menu diet ketogenik sangat dianjurkan karena kandungan glukosa rendah serta bersifat non-gluten.

Mengurangi ketergantungan terhadap terigu, perlu dicari sumber tepung dari bahan baku lokal lainnya. Labu kuning (Cucurbita moschata) merupakan salah satu alternatif sumber karbohidrat sebagai substitusi tepung terigu, sebab labu kuning banyak tumbuh di Indonesia dan hasilnya cukup melimpah. Padahal manfaat labu kuning bagi kesehatan sangat banyak yaitu menjaga kesehatan mata karena buah labu kuning mengandung vitamin A terutama beta karoten tinggi, menurunkan resiko penyakit kanker karena buah labu kuning memiliki pigmen yang dikenal sebagai beta karoten merupakan penyebab buah labu kuning berwarna oren kekuningan, menjaga kesehatan jantung karena mengandung serat, vitamin dan kalium (potasium) yang dapat membantu melindungi jantung dari berbagai penyakit,serta mengendalikan diabetes. Berkembangnya inovasi dalam dunia pangan, konsumen lebih menginginkan penyajian produk pangan yang praktis, sehingga labu kuning berpotensi untuk diolah menjadi tepung agar lebih praktis dan memperpanjang umur simpannya. Labu kuning memiliki daya simpan yang cukup lama namun volumenya besar dan mudah rusak dalam pengangkutan, sehingga perlu diolah menjadi suatu produk yang lebih tahan lama disimpan dan praktis, seperti tepung (Prabasini et al., 2013)

Menurut Juanda (2012) dalam jurnal (Triyani et al., 2013) Tepung labu kuning ini selanjutnya digunakan untuk membuat produk makanan seperti roti, cake, dan biscuit dengan cara mensubtitusikannya dengan tepung terigu, selama ini tepung labu kuning dapat menggantikan tepung terigu sebanyak $10 \%$ saja dari berat tepung keseluruhan. Hal ini dikarenakan tepung labu kuning tidak mengandung gluten seperti tepung terigu. Teknik modifikasi dapat digunakan untuk menanggulangi kelemahan-kelemahan dari pati dan menghasilkan pati dengan sifat-sifat yang lebih baik dan spesifik. Pati demikian ini disebut sebagai "pati termodifikasi (modified starch)". Dalam arti luas, setiap produk di mana sifat kimia dan atau sifat fisik pati biasa telah diubah disebut sebagai pati termodifikasi. Salah satu modifikasi saat ini yaitu dengan menggunakan hydrogen rich water. Hydrogen Rich Water (HRW) adalah air yang dihasilkan dari mesin ionisasi menggunakan proses elektrolisis. Mesin dapat merestrukturisasi air biasa dan mengubahnya menjadi air yang bersifat asam, basa, dan netral. HRW mampu merubah zat yang sangat merugikan kesehatan manusia (radikal bebas) menjadi air yang aman bagi kesehatan manusia. Air ini pun juga berfungsi meningkatkan daya tahan tubuh sehingga tubuh menjadi kebal terhadap segala macam penyakit seperti diabetes, kolestrol, penyakit jantung hingga alergi dan gangguan metabolisme (Nakao., et al,2010). Dengan demikian, tujuan penelitian ini adalah untuk mengetahui pengaruh perlakuan dengan perendaman labu kuning menggunakan hydrogen rich water terhadap karakteristik fisikokimia tepung serta tekstur, aroma dan rasa kue olahan tepung labu kuning.

\section{METODE PELAKSANAAN}

Tahap awal adalah persiapan bahan baku yakni proses pencucian dan pengupasan labu kuning, kemudian dilanjutkan dengan proses pemotongan dengan ketebalan $\pm 2 \mathrm{~mm}$. Tahap kedua adalah perendaman dengan hydrogen rich water $\mathrm{pH} 5$ dan 9, sebanyak 300 
Vol. 1, No. 1, Juni 2020

$\mathrm{mL}$ dengan variasi wajtu 1,2,3,4, dan 5 jam. Sampel kemudian dikeringkan menggunakan microwave lalu sampel dihaluskan menggunakan mesin blender dan diayak dengan ayakan 80 mesh. Tahap ketiga adalah analisis kualitas tepung sesuai dengan SNI 3150:2009. Analisis yang dilakukan adalah tekstur, rasa dan aroma olahan tepung labu kuning yang dihasilkan. Uji kesukaan, dilakukan dengan membuat kue menggunakan tepung labu kuning hasil modifikasi, lalu diberikan kepada sejumlah responden untuk kemudian memberikan tanggapan mengenai tekstur, aroma serta rasa kue tepung labu kuning yang dihasilkan.

\section{HASIL DAN PEMBAHASAN}

\section{A. Uji Warna, Aroma dan Tekstur}

Pada umumnya tepung labu kuning berwarna kuning. Warna kuning karena adanya pigmen karotenoid dari labu kuning. Karoten merupakan pigmen utama yang membentuk warna merah, oranye, kuning dan hijau pada buah atau sayur. Hasil yang diperoleh dapat dilihat pada Tabel 1.

Tabel 1. Pengaruh waktu perendaman terhadap warna tepung labu kuning termodifikasi Hydrogen Rich Water

\begin{tabular}{|c|c|c|c|c|}
\hline $\begin{array}{l}\text { Sampel per } \\
\end{array}$ & $\begin{array}{l}\text { tu } \\
\text { laman } \\
\text { n) }\end{array}$ & Warna & Tekstur & Aroma \\
\hline \multirow{5}{*}{$\begin{array}{c}\text { Labu } \\
\text { kuning } \\
\text { Dengan } \\
\text { Hydrogen } \\
\text { rich water } \\
\text { pH } 5\end{array}$} & 1 & $\begin{array}{l}\text { Kuning } \\
\text { Kecoklatan }\end{array}$ & Halus & $\begin{array}{l}\text { Labu } \\
\text { kuning }\end{array}$ \\
\hline & 2 & Kuning & Halus & $\begin{array}{l}\text { Labu } \\
\text { kuning }\end{array}$ \\
\hline & 3 & Kuning & Halus & $\begin{array}{l}\text { Labu } \\
\text { Kuning }\end{array}$ \\
\hline & 4 & Kuning & Halus & $\begin{array}{l}\text { Labu } \\
\text { Kuning }\end{array}$ \\
\hline & 5 & $\begin{array}{l}\text { Kuning } \\
\text { Pucat }\end{array}$ & Halus & $\begin{array}{l}\text { Labu } \\
\text { kuning }\end{array}$ \\
\hline \multirow{5}{*}{$\begin{array}{l}\text { Labu } \\
\text { kuning } \\
\text { Dengan } \\
\text { Hydrogen } \\
\text { rich water } \\
\text { pH } 9\end{array}$} & 1 & Kuning & Halus & $\begin{array}{l}\text { Labu } \\
\text { kuning }\end{array}$ \\
\hline & 2 & $\begin{array}{l}\text { Kuning } \\
\text { Kecoklatan }\end{array}$ & Halus & $\begin{array}{l}\text { Labu } \\
\text { kuning }\end{array}$ \\
\hline & 3 & $\begin{array}{l}\text { Kuning } \\
\text { Pucat }\end{array}$ & Halus & $\begin{array}{l}\text { Labu } \\
\text { kuning }\end{array}$ \\
\hline & 4 & $\begin{array}{l}\text { Kuning } \\
\text { Pucat }\end{array}$ & Halus & $\begin{array}{l}\text { Labu } \\
\text { kuning }\end{array}$ \\
\hline & 5 & $\begin{array}{l}\text { Kuning } \\
\text { pucat }\end{array}$ & Halus & $\begin{array}{c}\text { Labu } \\
\text { kuning }\end{array}$ \\
\hline \multicolumn{2}{|l|}{ Labu kuning } & \multicolumn{2}{|c|}{ kuning } & $\begin{array}{l}\text { labu tanpa } \\
\text { perendaman }\end{array}$ \\
\hline Terigu & - & Putih & Halus & Gandum \\
\hline
\end{tabular}


Vol. 1, No. 1, Juni 2020

Semakin lama waktu perendaman maka tingkat kecerahan warna tepung labu kuning semakin menurun. Sedangkan untuk tepung labu kuning tanpa perendaman didapatkan hasil warna kuning hal tersebut dikarenakan tepung belum terkontaminasi dengan zat apapun dan labu kuning memiliki pigmen karotenoid yang tinggi selain itu fungsi dari hydrogen rich water itu sendiri yaitu untuk memperbaiki kualitas warna dari labu kuning. Waktu yang tepat untuk pengeringan di microwave yaitu 15 menit karena dengan waktu selama 15 menit dengan ketebalan $2 \mathrm{~mm}$ menghasilkan labu kuning yamg tidak gosong. Warna yang optimal didapatkan pada waktu perendaman 3,4,5 jam dikarenakan ketiga waktu tersebut menghasilkan warna kuning pucat bukan kuning cearh sedangkan dari segi bau dengan lama waktu perendaman mempengaruhi kwalitas aroma tepung yang dihasilkan, jika dilihat dari bahan perendaman yaitu hidrogen rich water secara umum, tidak mempunyai bau yang menyengat sehingga aroma yang dihasilkan pada tepung itu semunya tidak beraroma menyengat tetapi menghasilkan bau khas labu kuning. Sedangkan menurut standar mutu tepung terigu susuai SNI 3751:2009 adalah tepung harus mempunyai bau normal yaitu harus bebas dari bau asing.

\section{B. Uji Kesukaan}

Uji kesukaan ini bertujuan untuk mengetahui kualitas tepung labu kuning termodifikasi hydrogen rich water jika dijadikan sebagai suatu makanan. Uji kesukaan ini dilakukan dengan cara membuat kue muffin dengan menggunakan tepung labu kuning termodifikasi sebagai bahan dasar tanpa menambahan baking powder dan essence yang dapat mengubah kualitas asli dari tepung labu kuning. Data disajikan pada Gambar 1.

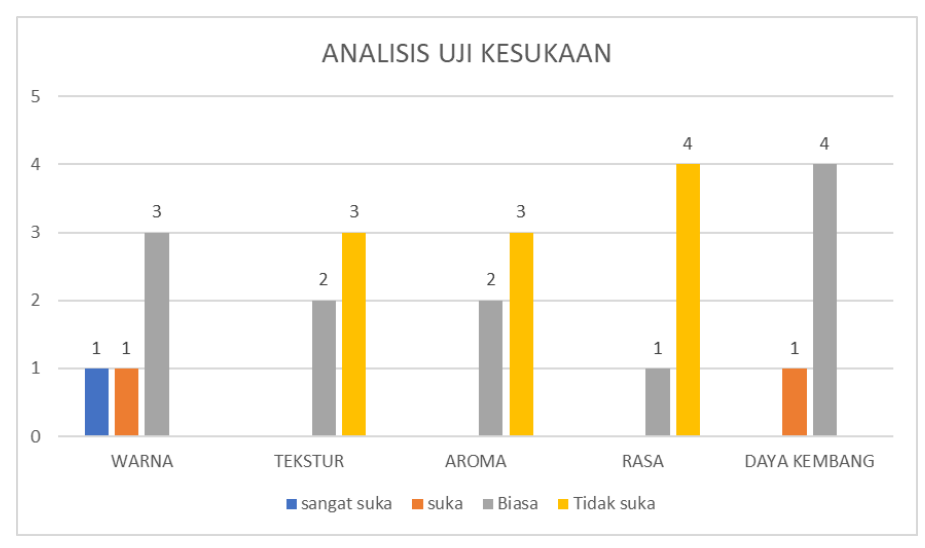

Gambar 1. Grafik hasil analisis uji kesukaan

Adapun responden dalam uji kesukaan ini yaitu mahasiswa Teknik Kimia Universitas Ahmad Dahlan, yang hasilnya ditunjukkan pada Gambar 1. Dari responden kami mendapatkan hasil yaitu tingkat pengembangan kue muffin kurang, dikarenakan kurangnya protein yang berakibat pada berkurangnya kemampuan adonan untuk mengembang. Hal ini disebabkan karena berkurangnya kandungan gluten dalam adonan. Gluten merupakan kandungan protein pada tepung terigu yang berfungsi untuk mempertahankan gas untuk mendapatkan volume yang diinginkan dan tekstur dalam sistem adonan. Glutenin dan prolamin adalah fraksi utama gluten. Sementara prolamin menyediakan viskositas adonan, glutenin bertanggung jawab untuk sifat elastis dan kohesif adonan. Produk kue muffin ini dapat mengembang 
Vol. 1, No. 1, Juni 2020

dengan baik jika tepung labu kuning dicampurkan dengan tepung terigu karena adanya kandungan gluten(Loelianda et al., 2017). Aroma kue muffin kurang disukai oleh responden karena memliki aroma yang khas. Aroma yang dihasilkan pada produk kue muffin, dipengaruhi oleh tepung labu kuning asli tanpa tambahan. Hal tersebut sejalan dengan penelitian yang telah dilakukan oleh Safriani (2015) pemanfaatan pasta labu kuning pada pembuatan mie kering, yang menyatakan bahwa tepung labu kuning memiliki aroma yang khas dan berbeda dengan aroma tepung terigu. Hal ini mengakibatkan mie yang dihasilkan akan memiliki aroma khas labu kuning. Semakin banyak tepung labu kuning yang digunakan maka aroma khas tersebut semakin nyata

\section{KESIMPULAN}

Pada pengabdian masyarakat ini dilakukan dengan cara memberikan penyuluhan tentang hasil dari penggunaan tepung labu kuning menggunakan hydrogen rich water Hasil sifat fisiokimia hampir mendekati tepung gandum, dari segi warna tepung labu kuning memiliki warna kuning pucat, tekstur tepung labu kuning halus, namun memiliki aroma pekat labu kuning. Hasil dari uji kesukaan diperoleh hasil bahwa kue muffin dengan bahan baku tepung labu kuning kurang diminati oleh masyarakat sehingga perlu ditambahkan/dicampur dengan tepung terigu.

\section{DAFTAR PUSTAKA}

Budiarti, G. indah, \& Sulistiawati, E. (2017). Modifikasi Tepung Labu Kuning Menggunakan Hydrogen Rich Water Sebagai Pengganti Gandum Pumpkin Flour' S Modification Using Hydrogen Rich Water As A Wheat's Substitute. Prosiding SENATEK, 335-340.

Hayuningsih, L. (2013). Daya Pembengkakan (Swelling power) Campuran Tepung Ganyong dan Tepung Terigu terhadap Tingkat Pengembangan dan Daya Terima Roti Tawar (Doctoral dissertation, Universitas Muhammadiyah Surakarta).

Jayaningrum, F. (2016). Aktivitas Media Smart Book dalam Meningkatkan Pengetahuan Tentang Penatalaksanaan Diabetes Mellitus pada Pasien Diabetes Mellitus di Puskesmas Kedungmundu Kota Semarang. Journal of Health Education, 1(2), 9.

Loelianda, P., Nafi, A., \& Windrati, wiwik siti. (2017). Substitusi Tepung Labu Kuning (Cucurbita Moschata Durch) Dan Koro Pedang (Canavalia Ensiformis L.) Terhadap Terigu Pada Pembuatan Cake Substitution. Jurnal Agroteknologi, 11(01), 1-10.

Prabasini, H., Ishartani, D., \& Rahadian, D. (2013). Kajian Sifat Kimia dan Fisik Tepung Labu Kuning (Cucurbita Moschata) dengan Perlakuan Blanching dan Perendaman dalam Natrium Metabisulfit (Na2S2O5). Jurnal Teknosains Pangan, 2(2), 93-102.

Triyani, A., Ishartani, D., \& A.M, D. R. (2013). Kajian Karakteristik Fisikokimia Tepung Labu Kuning (Cucurbita Moschata) Termodifikasi Dengan Variasi Lama Perendaman Dan Konsentrasi Asam Asetat. Jurnal Teknosains Pangan, 2(2), 30. 
SPEKTA

Jurnal Pengabdian Kepada Masyarakat : Teknologi dan Aplikasi

Vol. 1, No. 1, Juni 2020

Halaman ini sengaja dikosongkan. 